Available online on 15.02.2020 at http://jddtonline.info
Open Access to Pharmaceutical and Medical Research
unrestricted non-commercial use, provided the original work is properly cited

Open $\overbrace{\text { Access }}$

Research Article

\title{
Phytochemical screening, Antimycobacterial activity of three medicinal Cameroonians plants and Acute toxicity of hydroethanolic extract of Vitellaria paradoxa
}

\author{
Assam Assam Jean Paul 1*, Yumsu Tcham Marc Flaubert 2, Moni Ndedi Esther Del Florence 1, Betote Diboue Patrick Hervé 3,4, Fossi \\ Tchinda Cedric ${ }^{2}$, Penlap Beng Veronique ${ }^{2}$ \\ ${ }^{1}$ Department of Microbiology, Faculty of Science, University of Yaounde I P.0. Box 812, Yaounde, Cameroon \\ 2 Department of Biochemistry, Faculty of Science, University of Yaounde I P.0. Box 812, Yaounde, Cameroon \\ ${ }^{3}$ Department of Galenical Pharmacy and Pharmaceutical Law, Faculty of Medecine and Biomedical Sciences, University of Yaounde I ; P.O. Box \\ 812, Yaounde, Cameroon \\ ${ }^{4}$ Centre for Research on Medicinal Plants and Traditional Medicine, Institute of Medical Research and Medicinal Plants Studies, Yaounde ; P.O. \\ Box 13033, Yaounde, Cameroon
}

\begin{abstract}
Tuberculosis (TB) is an infectious disease caused by the Mycobacterium tuberculosis (M. tuberculosis) complex, resposible for health problems in developing countries. In Africa, various medicinal plants are traditionally used to treat TB. The aim of this study is to carry out the phytochemical screening, to evaluate the antimycobacterial activity of the crude extracts of three medicinal plants present in Cameroon (Zingiber officinale, Vitellaria paradoxa and Alstonia boonei) and the acute toxicity of hydroethanolic extract of Vitellaria paradoxa. The phytochemical screening was obtained by hydroethanolic extraction and decoction. Inhibitory parameters of antimycobacterial activities were determined using the microplate alamar blue assay against M. tuberculosis $H_{37} R v$ (ATCC 27294) and on one M. tuberculosis clinical strain. The crude extract with the best antimycobacterial activity was used for the acute toxicity assessment according to the OECD proto col. The results of the phytochemical screening revealed the presence of triterpenes and steroids in all the extracts, whereas phenols were only present in the decoction of Alstonia boonei. All extracts tested showed antimycobacterial activities. The hydroethanolic extract of $V$. paradoxa presented the best antimycobacterial activity with MICs of 78.13 and $625 \mu \mathrm{g} / \mathrm{mL}$ and MBCs of 78.13 and $2500 \mu \mathrm{g} / \mathrm{mL}$ respectively on $M$. tuberculosis $H_{37}$ R and on M. tuberculosis clinical strain. The results of the acute toxicity evaluation of $V$. paradoxa showed a lethal dose 50 greater than 5000 $\mathrm{mg} / \mathrm{kg}$ compared to control. The antimycobacterial activity of all the plant extracts used in this study justifies the traditional use of these medicinal plants on the treatment of TB.
\end{abstract}

Keywords: Zingiber officinale, Vitellaria paradoxa, Alstonia boonei, Phytochemical screening, Antimycobacterial activity, Acute toxicity.

Article Info: Received 29 Nov 2019; Review Completed 10 Jan 2020; Accepted 17 Jan 2020; Available online 15 Feb 2020

Cite this article as:

Assam Assam JP, Yumsu Tcham MF, Moni NEDF, Betote DPH, Fossi TC, Penlap BV, Phytochemical screening, Antimycobacterial activity of three medicinal Cameroonians plants and Acute toxicity of hydroethanolic extract of Vitellaria paradoxa, Journal of Drug Delivery and Therapeutics. 2020; 10(1-s):96-104 http://dx.doi.org/10.22270/jddt.v10i1-s.3848

*Address for Correspondence:

Assam Assam Jean Paul, Department of Microbiology, Faculty of Science, University of Yaounde I P.0. Box 812, Yaounde, Cameroon

\section{INTRODUCTION}

Mycobacterium tuberculosis (M. tuberculosis), the leading causative agent of tuberculosis (TB) is responsible for the morbidity and mortality of a large population worldwide 1 . It is widespread in poor countries, with more than $80 \%$ of cases occurring in Asia and Africa ${ }^{2}$. TB does not exhibit any symptom of disease except when impairment of immunity arises due to malnutrition, diabetes, malignancy and AIDS 3; however, about $10 \%$ of healthy individuals may develop active TB in their life time due to genetic factors.
The ability of TB to resist drugs and the influence of HIV epidemy has made the disease remain a devastating global public health problem 4 . In 2016, an estimated number of 10.4 million new TB infections were reported, on which $90 \%$ were adults, $65 \%$ were male and $10 \%$ were people living with HIV 5. This disease is responsible for approximately two million deaths annually ${ }^{6}$. The alarming rise of multidrug-resistant (MDR), extensively drug-resistant (XDR) and currently, totally drug resistant (TDR) $M$. tuberculosis strains, which are difficult to control with the currently available essential antitubercular drugs on the market, and 
the increased incidence of TB associated with viral infections such as HIV, have recently complicated the chemotherapeutics of TB 7. Indeed, the side effects of current anti-TB drugs used in long course in combination for the treatment of disease, lead to poor patient compliance and thus promoting the emmergence of resistant strains 8 . As a result, one of the current lines of research is the investigation of new natural compound endowed with antimycobaterial properties and non toxic, which can permit to fight effectively both susceptible and resistant strains of M. tuberculosis. Natural products of plant biodiversity have received considerable attention as potential anti-TB agents since they are proven templates for the development of new molecules against TB. Many antitubercular compounds that may prove to be useful leads for TB drug discovery have been derived from medicinal plants ${ }^{9}$.

In Africa, many plants are used against various respiratory tract infections, including: Zingiber officinale (Zingiberaceae) 10, Vitellaria paradoxa (Sapotaceae) ${ }^{10,11,12}$ and Alstonia boonei (Apocynaceae) 13,14 . Numerous scientific studies have shown that these plants have various biological properties 15, 16, 17, but very few have investigated the antimycobacterial properties of Zingiber officinale and Vitellaria paradoxa and so far to the best of our knowledge, no study has been carried out on extracts of Alstonia boonei.

Ginger (Z. officinale) in Cameroon is traditionally used in the villages of the Central Region for the treatment of respiratory diseases 18 and in the Littoral region, for the treatment of infectious disorders, such as pulmonary infections including TB 14. In Niger, it is used in the treatment of TB and other respiratory diseases 10 . Shea tree (V. paradoxa) is traditionally used in Cameroon against intestinal worms in children ${ }^{19}$, while in Niger it is used for the treatment of TB and other respiratory diseases ${ }^{10}$ and in the states of Bauchi and Ogun in Nigeria for the treatment of TB 11, 12. As for "devil tree" (A. boonei) ${ }^{20}$, it is traditionally used for the treatment of endocrino-metabolic, neurological, cardiovascular and infectious disorders such as pulmonary infections and TB ${ }^{14}$. In Kisangani, Congo (Zaire), it is used against throat diseases and $\mathrm{TB}{ }^{13}$. However in traditional medicine, the method of preparation commonly used for the use of these plants is the decoction ${ }^{18}$. The purpose of the present study, however, is to carry out the phytochemical screening, determine the antimycobacterial activity and evaluate the acute toxicity of crude extracts obtained by hydroethanolic extraction $\left(30^{\circ}\right.$ ethanol) and decoction of Zingiber officinale, Vitellaria paradoxa and Alstonia boonei.

\section{MATERIALS AND METHODS}

\subsection{Chemicals}

Rifampicin (Rif) were obtained from Sigma-Aldrich (St. Quentin Fallavier, France). Stock solutions at 1000 $\mu \mathrm{g} / \mathrm{mL}$ were filter sterilized and stored at $-20^{\circ} \mathrm{C}$. Working solutions were prepared at four times the final higher concentration in Middlebrook 7H9 supplemented with 2\% glycerol, 10\% OADC (oleic acid, albumin, dextrose, and catalase) and $0.05 \%$ (vol $/ \mathrm{vol}$ ) Tween 40 (Sigma). Alamar blue dye $0.01 \%$ (weight/volume) from Sigma-Aldrich (St. Quentin Fallavier, France) was prepared and sterilized by filtration, and stored at $4^{\circ} \mathrm{C}$ for up to 1 week. Kit SGM Italia were also obtained from Sigma-Aldrich.

\subsection{Collection and extraction of plant materials}

Fresh rhizomes of $Z$. officinale were purchased in August 2017 from three Markets (Mvog-beti, Mokolo and Acacia), Yaoundé, Center Region, Cameroon. The stem bark of $V$. paradoxa and A. boonei were harvested respectively in
September 2017 from Tcholliré village, North Region, Cameroon and in August 2017 from Kala village, Center Region, Cameroon. Botanical identification of the plants was performed at the Cameroon National Herbarium, where the voucher specimens were conserved under the reference numbers 14757/SRF/Cam (Z. officinale), 14591/SRF/Cam (V. paradoxa) and 1943/SRFK (A. boonei).

The fresh rhizomes of $Z$. officinale after being purchased in the different markets were washed with tap water and then cut and dried at room temperature away from light. The barks of $V$. paradoxa and $A$. boonei after harvest were directly cut and dried at room temperature away from light. Once well dried, they were finely crushed manually using mortar and pestle to obtain a powder. The extracts were obtained by two common extraction techniques, maceration and decoction.

According to maceration, The extracts were prepared as earlier described by combination of Prakash et al. (2005) 21 and Sourabie et al. (2012) 22 with slight modifications. One hundred and fifty grams of each powder were soaked with $750 \mathrm{~mL}$ of $30 \%$ ethanol in ratio 1:5 (w/v) and mixed intermittently for $48 \mathrm{~h}$. This process was repeated three times and subsequently, the suspension was filtered using Whatman No.1 filter paper. The filtrate obtained was concentrated using a rotary evaporator at $79^{\circ} \mathrm{C}$, the residue was lyophilized and stored at room temperature.

The extracts obtained by decoction were prepared as earlier described by Sourabie et al. (2012) ${ }^{22}$ with slight modifications. A total of $1000 \mathrm{~mL}$ of boiling distilled water was poured into $150 \mathrm{~g}$ of plant powder under constant shaking with magnetic stirrer for $15 \mathrm{~min}$. This operation was repeated twice and at the end of the extraction, it was filtered through nylon mesh followed by Whatman filter paper No.1. The filtrate was then concentrated under reduced pressure on rotary evaporator at $40^{\circ} \mathrm{C}$, the residue was lyophilized and stored at room temperature.

\subsection{Experimental animals}

Albino Wistar rats aged 8 to 12 weeks old, weighing between $125 \mathrm{~g}$ to $169 \mathrm{~g}$ were obtained from the animal house, of the Department of Animal Biology and Physiology, University of Yaounde I, Cameroon. They were allowed to acclimatize for a period of 2 weeks. They were maintained in clean metabolic cage-sand, placed in a wellventilated room conditions with a temperature of $26^{\circ} \mathrm{C}$ to $28^{\circ} \mathrm{C}$, photoperiods of 12 hours light and 12 hours darkness; humidity of $40 \%$ to $60 \%$ (Rong et al., 2009) ${ }^{23}$.

\subsection{Phytochemical screening}

The various plant extracts were screened for plant metabolites using the lyophilized materials. It was carried out in accordance with standard methods described by Harbone (1998) 24 and Evans (2000) 25. These metabolites include alcaloid, phenols, polyphenols, tanins, saponins, flavonoids, triterpens, steroids, anthocyanins and anthraquinones.

\subsection{In vitro antimycobacterial assay}

\subsubsection{Bacterial strains and growth conditions}

The studied microbial species included two strains of mycobacteria, namely, a drug-susceptible strain of $M$. tuberculosis $H_{37} R v$ (ATCC 27294) and one M. tuberculosis clinical strain (MTCS). They were maintained on Lowenstein-Jensen (LJ) slopes and cultured on Middlebrook 7H9 broth supplemented. Cultures were grown aerobically on supplemented broth medium at $37^{\circ} \mathrm{C}$. 


\subsubsection{Microplate alamar blue assay (MABA)}

All samples were tested against $M$. tuberculosis using the microplate dilution method 26. The MIC and MBC of all samples against $M$. tuberculosis strains were tested using the MABA according to Collins and Franzblau, 199727. Briefly, representative colonies of $M$. tuberculosis from Lowenstein-Jensen (LJ) slope were suspended in $1 \mathrm{~mL}$ distilled water and the turbidity was adjusted to match McFarland tube No.1 ( $\left.10^{7} \mathrm{CFU} / \mathrm{mL}\right)$ and further diluted to 1:25 in Middlebrook 7H9 broth supplemented and used as inoculums. One hundred microliters of Middlebrook 7H9 broth supplemented was dispensed in each well of a sterile flat-bottom 96-well plate, and serial twofold dilutions of the crude extracts and each positive control drug were prepared directly in the plate. One hundred microliters of inoculum was added to each well. A growth control and a sterile control were also included for each mycobacterial strain. Sterile water was added to all perimeter wells to avoid evaporation during incubation. The plates were covered, sealed in plastic bags, and incubated at $37^{\circ} \mathrm{C}$ under a normal atmosphere. After incubation for about 7 days, $20 \mu \mathrm{L}$ of Alamar blue solution were added to the wells. The plates were re-incubated overnight at the same temperature. A color change from blue to pink indicated bacterial growth. All experiments were carried out in triplicate. The minimum inhibitory concentration (MIC) was defined as the lowest concentration of the crude extract or positive control drug that prevented this change in color and the minimum bactericidal concentration (MBC) corresponded to the minimum concentration of extract that did not produce a shift in cultures re-incubated in fresh medium. The classification of the extracts was made by calculating the ratio MBC/MIC as described by Carbonelle et al. (1987) 28 and Gatsing et al. (2006) ${ }^{29}$ for which, an antimicrobial substance is considered bactericidal when the ratio $\mathrm{MBC} / \mathrm{MIC} \leq 4$ and bacteriostatic when the ratio MBC/MIC $>4$.

\subsection{Toxicity test}

\subsubsection{Acute toxicity study}

Acute toxicity study was performed according to the procedures outlined by the Organization for Economic Co-operation and Development guidelines 423 30. Twelve Wistar female albino rats were used for this study. The rats were randomly divided into 3 groups of 4 animals each, with the first group as the control. The hydroethanolic extract of $V$. paradoxa was administered to rats in groups 2 and 3 in single oral doses of $2000 \mathrm{mg} / \mathrm{kg}$ and $5000 \mathrm{mg} / \mathrm{kg}$ body weight respectively, by intra gastric gavage using oral cannula. The control group (Group 1) received an equal volume of distilled water. Observations of toxic symptoms were made and recorded within the first hour, four hours and subsequently for 24 hours after administration of the extract. Behavioral parameters and mortality were also monitored closely for 14 days. Lethal dose in $50 \%$ of the total population (LD50) was interpolated using OECD $\operatorname{method}^{30}$.

\subsubsection{Body weight}

The rats in all the groups were weighed using a sensitive balance, before starting the administration of extract, every two days during the observation period and once on the day of sacrifice. Doses of the extract administered were adjusted accordingly.

\subsubsection{Relative organ weight}

On day 14 of the observation period, all the animals were euthanised by exsanguination under chloroform anesthesia. The rats were later sacrificed through lumbar dislocation. Different organs namely the kidneys, liver, spleen, lungs and heart were carefully dissected out and weighed in grams (absolute organ weight). The relative organ weight of each animal was then calculated as follows:

Relative organ Weight $=\frac{\text { Absolute organ weight }(\mathrm{g})}{\text { Body Weight of rat sacrifice day }(\mathrm{g})} X 100$

\subsubsection{Biochemical analyses}

Blood samples were collected from the animals through cardiac puncture, into clean and dry tubes. The blood collected was allowed to clot and then centrifuged at $5000 \mathrm{rpm}$ for 10 minutes. The serum was separated and kept frozen at $-4^{\circ} \mathrm{C}$ until required for analysis (Aniagu et al., 2005) ${ }^{23}$. The separated clear sera collected were used for the biochemical assays of AST, ALT and Creatinin using SGM Italia reagent kit.

\subsection{Statistical analysis}

The experimental results were expressed as the Mean \pm S.E.M. Statistical significant difference in parameters amongst groups was determined by One way ANOVA followed by Tukey's multiple range test using GraphPad version 7.0. $\mathrm{P}<0.05$ was considered to be significant.

\section{RESULTS AND DISCUSSION}

The extraction yields and the physical properties of the various extracts obtained by hydroethanol maceration and decoction are recorded in Table I. These yields ranging from 5.97 to $13.63 \%$ respectively for $V$. paradoxa bark and $Z$. officinale rhizomes for maceration. Meanwhile, in decoction they ranging from 2.36 to $27.77 \%$ respectively for A.boonei bark and Z. officinale rhizomes. For two (02) of the three (03) samples, the extraction yield obtained by decoction is greater than that obtained by hydroethanol maceration for a similar sample. These results corroborate those of Mahmoudi et al. (2013) ${ }^{31}$ and Lehout and Laib (2015) ${ }^{32}$, who made the same observation in their work. However, for A.boonei bark, the extraction yield by hydroethanol maceration was higher than that of the decoction. This reduction in the extraction yield of $A$. boonei by decoction would probably be due to the denaturation of certain thermosensitive compounds by heat, as presented by the work of Kémajou et al. (2012) 33, who evaluated the influence of drying temperature on the active ingredients (total alkaloids) of $A$. boonei; where they found that the total alkaloids content of the bark extract gradually decreases as the drying temperature increases. In addition, rhizomes of $Z$. officinale had the best extraction yield, both in hydroethanol maceration and decoction. This observation could be explained by the fact that rhizomes of $Z$. officinale contain more active compounds. It is in the same light that the work of Mariangela et al. (2015) ${ }^{34}$, demonstrated that in addition to the pulp of rhizomes of $Z$. officinale, the skin of this latter also contains active compounds and that it contains more non-polar compounds and even twice as many polyphenolic compounds as the pulp. In fact, according to Bruneton (1999) 35 the extraction yields of the plants are different depending on the species of the plant, the organ and the extraction solvent. The determination of the extraction yield makes it possible to assess the total extract of each species and organ of the plant thus making it possible to estimate the quantity of the part of the plant to be harvested if necessary to allow the rational use of these plant species ${ }^{36}$. 
Table I: Extraction yield and physical properties of the extracts

\begin{tabular}{|c|c|c|c|c|c|}
\hline \multirow{2}{*}{$\begin{array}{c}\text { Extraction } \\
\text { types }\end{array}$} & \multirow{2}{*}{$\begin{array}{l}\text { Extraction } \\
\text { solvents }\end{array}$} & \multirow[t]{2}{*}{ Extract types } & \multirow{2}{*}{$\begin{array}{c}\text { Extraction yield } \\
(\%)\end{array}$} & \multicolumn{2}{|c|}{ Physical properties of extracts obtained } \\
\hline & & & & Color & State \\
\hline \multirow{3}{*}{$\begin{array}{l}\text { Extraction by } \\
\text { Maceration }\end{array}$} & \multirow{3}{*}{$\begin{array}{l}\text { Hydroethanol } \\
(70 / 30, v / v)\end{array}$} & Mz.o & 13,63 & Yellow & Liquid \\
\hline & & $M_{V . p}$ & 5,97 & Brick red & Liquid \\
\hline & & M A.b & 10,97 & Pale yellow & Liquid \\
\hline \multirow{3}{*}{$\begin{array}{l}\text { Extraction by } \\
\text { Decoction }\end{array}$} & \multirow{3}{*}{ Distilled water } & D Z.o & 27,77 & Yellow & Viscous \\
\hline & & D v.p $_{\text {v }}$ & 10,36 & Brick red & Liquid \\
\hline & & $D_{\text {A.b }}$ & 2,36 & Yellow & Liquid \\
\hline
\end{tabular}

Legend: $\mathrm{M}=$ Macerat; D = Decoction; Z. $\mathrm{o}=$ Zingiber officinale $; \mathrm{V} . \mathrm{p}=$ Vitellaria paradoxa $; \mathrm{A} . \mathrm{b}=$ Alstonia boonei

The results of the phytochemical screening of the extracts are shown in Table II. From this phytochemical test, it is seen that all the extracts contain triterpenes and steroids, and that among these extracts, only the decoction of $A$. boonei contains phenols. This could be explained by the fact that during extraction, the heat produced during the decoction would have caused the breaking of certain bonds, thus causing the formation of phenols. This is in line with results obtained by Ross et al. (2011) ${ }^{37}$ who reported that under the effect of high temperature, there is partial degradation of lignin, leading to the release of phenolic acid derivatives. Amongst other things, saponins would probably be sensitive to heat because their presence is considerably reduced, or even absent in decoction compared to maceration in all samples. Alkaloids, saponins, flavonoids and steroids present in $Z$. officinale extract have also been reported in the work of Kobo et al. (2014) 38. Amongst others, Amari (2016) ${ }^{39}$ in his work highlighted the presence of flavonoids, triterpenes and the absence of anthraquinones in Z. officinale extract as presented by the results obtained. In addition, Ogudo et al. (2014) 40 also reported in their work the presence of alkaloids, flavonoids and the absence of phenols as observed in the present work, but the absence of saponins and anthraquinones in their extract does not agree with the results here obtained. On the other hand, the absence of tannins in the extract presented here runs counter to the results obtained by all of them. However, their study did not indicate the presence of polyphenols and anthocyanins which were rather present in this study. This test permitted us to reveal the presence alkaloids, saponins, flavonoids, triterpenes and steroids in $A$. boonei extract These results concords with those of Voukeng et al. (2016) 41 and Opoku and Akoto. (2015) ${ }^{42}$, who used the bark and roots of $A$. boonei respectively. Nevertheless, the presence of anthraquinones reported by these works are contrary to those of Opoku and Akoto. (2015) ${ }^{42}$. Owolabi et al. (2014) 43 also reported the presence of alkaloids, saponins, flavonoids, anthraquinones and the absence of tannins in $A$. boonei leaves just as those obtained with the bark in this study. None of the previous studies tested for presence of phenols and anthocyanins which were however absent and present respectively in this study. The presence of alkaloids, tannins, saponins and the absence of phenols evidenced by this phytochemical test in $V$. paradoxa bark extract coroborates with the results obtained by El-Mahmood et al. (2008) 44, while the anthraquinones present in this extract were absent. These latter did not search for polyphenols, flavonoids, triterpenes, steroids and anthocyanins, which were all present in this study. In addition, Ndukwe et al. (2007) 45 noted the absence of flavonoids in their extracts, which is contrary to that of this work and the presence of alkaloids, saponins and steroids, which is similar to the results obtained in this study. However, Fodouop et al. (2017) ${ }^{46}$ showed the presence of alkaloids, polyphenols, tannins and flavonoids in the leave extract of $V$. paradoxa similar to that in this study. On the other hand, the presence of phenols and the absence of saponins, triterpenes, steroids, anthocyanins and anthraquinones reported in their results do not agree with those presented here. The difference in chemical composition of the extracts presented by the results of this work and others can be explained by the nature of the solvent, the part of the plant used, the technique of extraction and the nature of the soil on which the plant has grown, as reported by several authors such as Bruneton (1999) 47 and Nyegue (2006) 48, who have demonstrated that the chemical composition of plant Essential oils can vary depending on the climate and the nature of the soil. In addition, Hudaib et al. (2002) 49 also indicated that theperiod of collection, method of conservation, genetic factors and vegetative cycle of the plant can also influence the variability of the chemical composition.

Table II: Phytochemical Screening

\begin{tabular}{|c|c|c|c|c|c|c|}
\hline \multirow{3}{*}{$\begin{array}{c}\text { Families of secondary } \\
\text { metabolites }\end{array}$} & \multicolumn{6}{|c|}{ Crudes extracts } \\
\hline & \multicolumn{3}{|c|}{ Hydroehanolic Maceration } & \multicolumn{3}{|c|}{ Decoction } \\
\hline & Mz. o & Mv. p & $\mathbf{M}_{\text {A. } \mathbf{b}}$ & Dz. o & Dv. p & $\mathbf{D}_{\text {A. b }}$ \\
\hline Alkaloids & ++ & + & +++ & $+/-$ & - & + \\
\hline Phenols & - & - & - & - & - & ++ \\
\hline Polyphenols & + & + & + & ++ & + & $+/-$ \\
\hline Tanins & - & ++ & - & - & ++ & $+/-$ \\
\hline Saponins & ++ & + & + & - & - & - \\
\hline Flavonoids & $+/-$ & ++ & + & - & ++ & $+/-$ \\
\hline Triterpenes & + & + & + & + & + & + \\
\hline Steroids & + & + & + & + & + & + \\
\hline Anthocyanins & + & ++ & ++ & + & ++ & + \\
\hline Anthraquinones & - & + & + & $+/-$ & + & + \\
\hline
\end{tabular}

Legend : : : absent; +/- : presence as a trace; + : weak presence ; ++ : average presence ; +++ : high presence 
The antimycobacterial tests on $M$. tuberculosis $H_{37} R v$ and MTCS made it possible to determine the minimal inhibitory concentration (MIC) and the minimal bactericidal concentration (MBC) and the MBC/MIC ratio on these latter and grouped respectively in Tables III and IV. On $M$. tuberculosis $H_{37} R v$, the best MIC of $78.13 \mu \mathrm{g} / \mathrm{mL}$ also representing the best MBC was obtained with the bark of $V$. paradoxa both with maceration and decoction. The classification of these extracts shows that, only the extract of A. boonei obtained by hydroethanolic maceration is bacteriostatic. However, the MIC of $1250 \mu \mathrm{g} / \mathrm{mL}$ obtained with $Z$. officinale extract on M. tuberculosis $H_{37} R v$ is eight times lower than that reported by Nguta et al. (2016) ${ }^{50}$ on the same strain that was $10,000 \mu \mathrm{g} / \mathrm{mL}$. Furthermore, Ballo (2013) ${ }^{19}$ in his work with V. paradoxa leaves obtained via a $70^{\circ}$ ethanol maceration of this latter, a MIC of $125 \mu \mathrm{g} / \mathrm{mL}$ on $H_{37} R v$. The present study with the bark of this latter by maceration with ethanol $30^{\circ}$ revealed a MIC of $78.13 \mu \mathrm{g} / \mathrm{mL}$ on the same strain. On the other hand, on the MTCS, the best MIC $(625 \mu \mathrm{g} / \mathrm{mL})$ and MBC $(2500 \mu \mathrm{g} / \mathrm{mL})$ was obtained with the hydroethanolic extract of $V$. paradoxa. All these extracts were bactericidal on the MTCS, except the decoction of $Z$. officinale which could not be classified considering that its MBC could not be determined (it did not belong to the range of the concentrations). The significant difference between the results obtained in this study and those of the other studies could be explained on the one hand by the difference in the chemical composition of plant organs, which is a function of different factors such as climate, soil type 47,48 , the period of collection, the method of conservation, genetic factors and the vegetative cycle of the plant 49 and on the other hand the nature of the solvent used Paiva et al. (2010) 51 showed that, depending on the polarity of the extraction solvents, the metabolites present in the extracts differ in their polarity and structure and hence, the antimicrobial activities of the compounds extracted from plants changes with a change in structure. It is in this sense that Cowan (1999) 52 alluded to the example between catechol and pyrogallol, both of which are hydroxylated phenols that have been shown to be toxic to microorganisms. Catechol has two hydroxyl groups and pyrogallol has three hydroxyl groups. The site (s) and number of groups on the aromatic ring are thought to be related to their relative toxicity to microorganisms, with evidence that increased hydroxylation leads to increased toxicity. In addition, some authors have found that more strongly oxidized phenols are more inhibitory ${ }^{52}$. It also appears from the results of this work that, in general, the hydroethanolic extracts were more active than those obtained by decoction on the two strains. Nevertheless, despite the fact that extracts obtained by decoction generally contain more chemical compounds due to their high yield, they are still less active than hydroethanolic extracts. This could be explained by the difference in concentration of active ingredients in plant extracts ${ }^{53}$. Indeed, decoction despite their high yield contain a low concentration of active ingredients with antimycobacterial properties, compared to extracts obtained by hydroethanolic maceration, which for their low yield contain a large number of compounds with antimycobacterial properties. This low decoction activity can also be explained by the fact that the antimycobacterial activity of the compounds in these extracts would be masked by other compounds present in the extract 54 . According to Kuete (2010) 55 the activity of plant extracts can be classified on the basis of MICs obtained in antimicrobial tests. Thus, it can be: significant (MIC $<100 \mu \mathrm{g} / \mathrm{mL})$, moderate $(100<$ MIC $<625 \mu \mathrm{g} / \mathrm{mL}$ ) or low (MIC $>625 \mu \mathrm{g} / \mathrm{mL}$ ). In this rank of idea, among the hydroethanolic extracts, the activity was significant for the bark of $V$. paradoxa (MIC $=78.13 \mu \mathrm{g} / \mathrm{mL}$ ), moderate for the bark of $A$. boonei (MIC $=156 \mu \mathrm{g} / \mathrm{mL}$ ) and low for rhizomes of $Z$. officinale (MIC $=1250 \mu \mathrm{g} / \mathrm{mL}$ ) on $M$. tuberculosis $H_{37} R v$. In addition, with decocts on $M$. tuberculosis $H_{37} R v$, the activity was significant for the bark of $V$. paradoxa (MIC $=78.13 \mu \mathrm{g} / \mathrm{mL}$ ), low for the bark of $A$. boonei and rhizomes of $Z$. officinale (respectively at MICs of 2500 and $5000 \mu \mathrm{g} / \mathrm{mL}$ ). On the other hand, on the clinical strain of $M$. tuberculosis, the activity of hydroethanolic extracts was moderate for bark of $V$. paradoxa (MIC $=625$ $\mu \mathrm{g} / \mathrm{mL}$ ) and low for all other extracts (with MICs of 2500 and $5000 \mu \mathrm{g} / \mathrm{mL}$ respectively for $A$. boonei and $Z$. officinale in hydroethanolic maceration while in decoction, MICs were 1250,5000 and $10,000 \mu \mathrm{g} / \mathrm{mL}$ respectively for $V$. paradoxa, A. boonei and Z. officinale). Seen these results, this clinical isolate would probably be resistant. Indeed, by observing MIC obtained on this isolate with the reference anti-TB drug (Rifampicin), which was $3.91 \mu \mathrm{g} / \mathrm{mL}$ this result goes in the same line as that of Gordien et al. (2009) 56 who in their study obtained a MIC greater to $3.29 \mu \mathrm{g} / \mathrm{mL}$ on a Rifampicinresistant isolate. This seems to confirm the resistant character of this clinical isolate and in particular resistant to Rifampicin. Amongst others, all decocts had a weak activity on the clinical strain. The antimycobacterial activities of these extracts could be explained by the presence of alkaloids, phenols, polyphenols, flavonoids, quinones, terpenoids and steroids (Brent, 2003) ${ }^{57}$. However, Kuete et al. (2010) ${ }^{55}$ showed the inhibitory activity of flavonoids of Dorstenia barteri on M. tuberculosis, while Gordien et al. (2009) 56 revealed the antimycobacterial activities of terpenoids Juniperus communis $\mathrm{L}$ on $M$. tuberculosis. In addition, Kuete et al. (2009) 58 presented the inhibitory activity of naphthoquinones from two species of Diospyros, Diospyros canaliculata and Diospyros crassiflora on $M$. tuberculosis. As a result, anthraquinones belonging to the same family as naphthoquinones and having the same functional group would probably also have a role in the antimycobacterial potential of the extracts where they are present. The antimycobacterial activity exerted by rhizome extracts of $Z$. officinale is probably due to the gingerol contained in these rhizomes ${ }^{59}$. Amongst others, Moustafa et al. (2016) 17 reported the presence of three phenolic compounds quercetin, catechin and epicatechin in the bark of V. paradoxa while the work of Raju et al. (2015) 60 showed the inhibitory activity of quercetin and epicatechin on $M$. tuberculosis. This could explain the antimycobacterial activity of $V$. paradoxa bark extracts in this study. So far, to the best of our knowledge, no scientific study has evaluated the antimycobacterial properties of $A$. boonei, however Adotey et al. (2012) ${ }^{61}$ recalled in their works that bark of $A$. boonei were isolated from alkaloids, the major ones being echitamine and echitamidine and triterpenoids such as lupeol, ursolic acid and $\beta$-amyrin. These metabolites are thus likely to be responsible for the antimycobacterial activity of this latter. 
Table III: Activity levels (MIC and MBC), MBC/MIC ratio and extracts classification against M. tuberculosis $H_{37} R v$

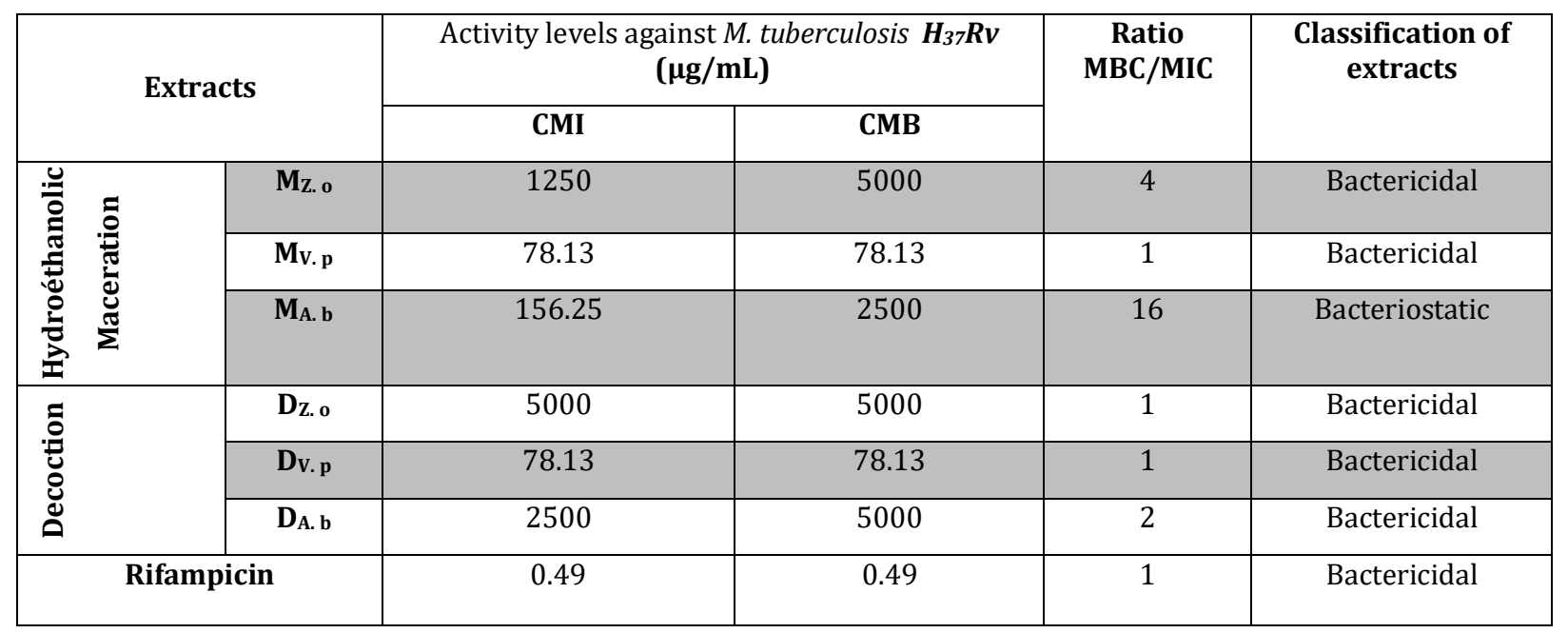

Table IV: Activity levels (MIC and MBC), MBC/MIC ratio and extracts classification against the MTCS

\begin{tabular}{|c|c|c|c|c|c|c|}
\hline \multirow{2}{*}{\multicolumn{3}{|c|}{ Extracts }} & \multicolumn{2}{|c|}{ Activity levels against MTCS $(\mu \mathrm{g} / \mathrm{mL})$} & \multirow{3}{*}{$\begin{array}{c}\text { Ratio } \\
\text { MBC/MIC } \\
2\end{array}$} & \multirow{3}{*}{$\begin{array}{c}\begin{array}{c}\text { Classification of } \\
\text { extracts }\end{array} \\
\text { Bactericidal }\end{array}$} \\
\hline & & & CMI & CMB & & \\
\hline \multirow{3}{*}{ 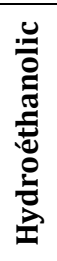 } & \multirow{3}{*}{ 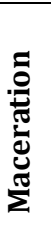 } & Mz. o & 5000 & 10,000 & & \\
\hline & & Mv. p & 625 & 2500 & 4 & Bactericidal \\
\hline & & $\mathbf{M}_{\text {A. } \mathbf{b}}$ & 2500 & 5000 & 2 & Bactericidal \\
\hline \multirow{3}{*}{ 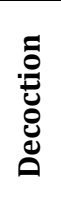 } & & D. o & 10,000 & N.d & / & / \\
\hline & & $\mathbf{D}_{\text {V. } \mathbf{p}}$ & 1250 & 5000 & 4 & Bactericidal \\
\hline & & $\mathbf{D}_{\text {A. b }}$ & 5000 & 10,000 & 2 & Bactericidal \\
\hline \multicolumn{3}{|c|}{ Rifampicin } & 3.91 & 3.91 & 1 & Bactericidal \\
\hline
\end{tabular}

Legend: N.d = Not determined

The hydroethanolic extract of $V$. paradoxa had the best antimycobacterial activity on both strains. The results of the acute toxicity evaluation of this extract revealed that the single administration of the 2000 and $5000 \mathrm{mg} / \mathrm{kg}$ doses of this extract to healthy female rats caused no evidence of apparent toxicity after the first 4 hours. It had no effect on the behavior of the animals (mobility, appearance of the coat, aspect of the buttocks, eye colors, ...) in comparison with the control. In addition, no deaths were noted in the experimental groups after 14 days of study. This suggests that the lethal dose 50 (LD50) of this extract would be greater than $5000 \mathrm{mg} / \mathrm{kg}$ and that this latter would be classified according to the Globally Harmonized Classification System (GHS) to category 5 of low or no toxic substances ${ }^{62}$. These results are similar to those obtained by Mainasara et al. (2016a) ${ }^{63}$ who also showed that the LD50 of the methanolic extract of $V$. paradoxa bark was greater than $5000 \mathrm{mg} / \mathrm{kg}$. Figure 1 illustrates the effects of the hydroethanolic extract of $V$. paradoxa on the weight variation of the rats. It shows that animal body weights increased exponentially the first two days after treatment, then varied irregularly until the fourteenth day for all test groups and sensibly in a regular manner for the normal group. However, no significant difference in weight was observed between the animals treated with this extract at doses of 2000 and $5000 \mathrm{mg} / \mathrm{kg}$ and the control. In the same rank of idea, Mainasara et al. (2016b) 64 demonstrated by their work that the chronic administration of methanolic extract of $V$. paradoxa at doses up to $400 \mathrm{mg} / \mathrm{kg}$ for 30 days did not result in a significant variation in the weight of the rats during the period of treatment. The relative weight of the kidneys, liver, spleen, lungs and heart of the animals that received this extract after a 14-day follow-up is summarized in Figure 2. No significant difference $(p>0.05)$ was observed between the relative weight of organs of animals treated at doses of 2000 and $5000 \mathrm{mg} / \mathrm{kg}$ of the hydroethanolic extract of $V$. paradoxa compared to control. Its effect on transaminase activity (AST and ALT) and creatinin concentration is shown in Table IV. No significant differences ( $p>0.05)$ in AST and ALT activities and creatinin concentration were observed between animals treated at 2000 and $5000 \mathrm{mg} / \mathrm{kg}$ of this extract compared to control. 
W eight evolution between Control and V.p

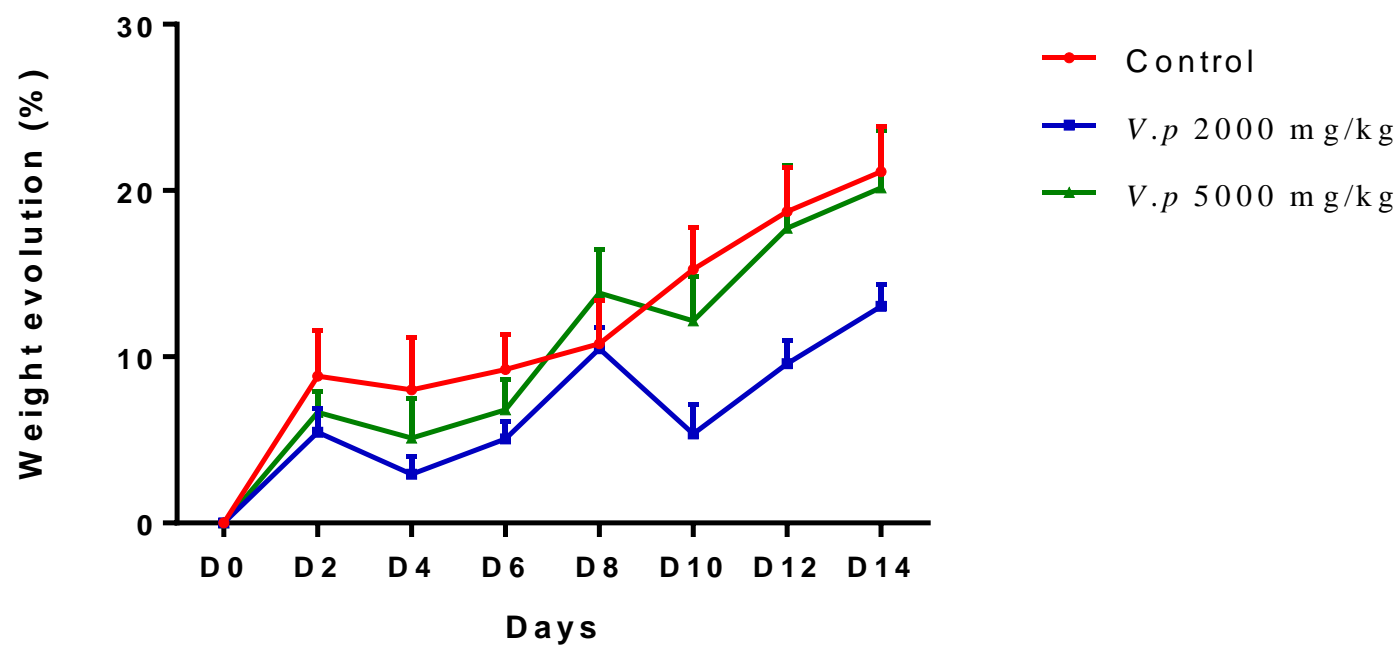

Figure 1 : Effects of hydroethanolic extract of V. paradoxa bark on the weight evolution of animals in acute toxicity

Each point represents the mean $\pm \mathrm{SEM} ; \mathrm{n}=4$; Control : rats treated with distilled water; $V . p 2000 \mathrm{mg} / \mathrm{kg}$ and $V$. $p$ $5000 \mathrm{mg} / \mathrm{kg}$ : rats treated with hydroethanolic extract of $V$. paradoxa respectively at doses of 2000 and $5000 \mathrm{mg} / \mathrm{kg}$.

\section{Relative weight of organs between Control and $V . p$}

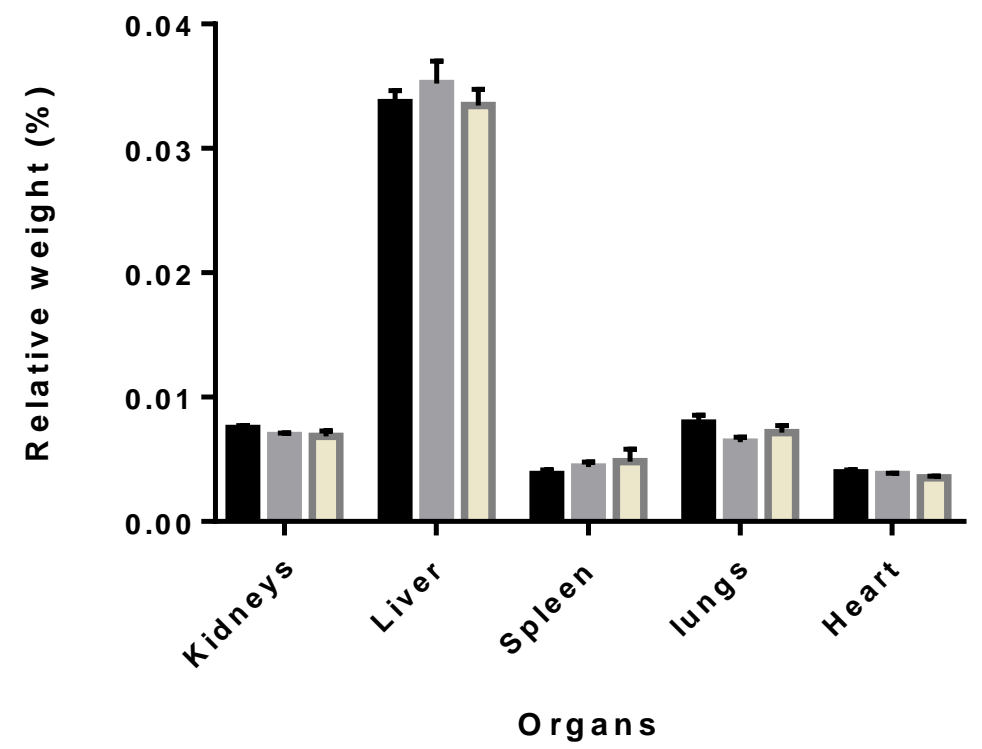

Figure 2 : Relative weight of animal organs that received hydroethanolic extract of $V$. paradoxa bark

Each bar represents the mean $\pm \mathrm{SEM} ; \mathrm{n}=4$; Control: rats treated with distilled water; $V . p 2000 \mathrm{mg} / \mathrm{kg}$ and $V . p 5000$ $\mathrm{mg} / \mathrm{kg}$ : rats treated with hydroethanolic extract of $V$. paradoxa respectively at doses of 2000 and $5000 \mathrm{mg} / \mathrm{kg}$.

Table IV : Effects of hydroethanolic extract of $V$. paradoxa on transaminase activity (AST and ALT) and creatinin concentration

$$
\begin{array}{lll}
\text { Control V.p } \mathbf{2 0 0 0} \mathrm{mg} / \mathbf{k g} & \text { V. } p 5000 \mathrm{mg} / \mathbf{k g}
\end{array}
$$

\begin{tabular}{|lrrr|}
\hline AST (UI/L) & $4,481 \pm 0,397$ & $5,471 \pm 0,600$ & $3,977 \pm 0,563$ \\
\hline ALT (UI/L) & $4,263 \pm 0,689$ & $5,878 \pm 0,333$ & $4,190 \pm 0,563$ \\
Créatinin $(\mu \mathrm{mol} / \mathrm{L})$ & $95,504 \pm 19,500$ & $95,504 \pm 10,817$ & $72,158 \pm 11,214$ \\
\hline
\end{tabular}




\section{CONCLUSION}

The results of this study highlights the importance to be given to plants, since they have many properties including antimycobacterial. The antimycobacterial potential and the non-toxicity of hydroethanolic extract (ethanol $30^{\circ}$ ) of the bark of $V$. paradoxa justifies the traditional use of this plant for the treatment of TB. However, given the fact that M. tuberculosis $H_{37} R v$ was particularly sensitive to extracts of $V$. paradoxa and $A$. boonei (respectively strong and moderate activities), these plants are excellent candidates for the search for new molecules that can act against $M$. tuberculosis $H_{37} R v$.

\section{Acknowledgements}

Authors are thankful to the " Central Africa Network for Tuberculosis, HIV / AIDS and Malaria (CANTAM) " project through its coordinator Professor Francine NTOUMI and EDCTP (European and Developping Countries Clinical Trials Partnership), for technical and financial support. Authors are also thankful to the Cameroon National Herbarium (Yaounde) for the plant identification.

Conflicts of Interest: The authors declare that there is no conflict of interest regarding the publication of this paper.

\section{REFERENCES}

1- Baldwin, P.R., Reeves. A.Z., Powell, K.R., Napier, R.J., Swimm, A.I., Sun, A., Giesler, K., Bommarius, B., Shinnick, T.M., Sny-der, J.P., Liotta, D.C.,Monocarbonyl analogs of curcumin inhibit growth of antibiotic sensitive and resistant strains of Mycobacterium tuberculosis. European Journal of Medicinal Chemistry, 2015; 6 (92):693-9.

2- Zager, E.M., McNerney, R., Multidrug-resistant tuberculosis. BMC Infectious Diseases, 2008; 8:10.

3- Antony, M., James, J., Misra, C.S., Sagadevan, L.D.M., Veettil, A.T., Thankamani, V., Anti- mycobacterial activity of the plant extracts of Alstonia scholaris. International Journal of Current Pharmaceutical Research 2012; 4 (1):40 - 42

4- Tang, J., Yam, WC., Chen, Z., Mycobacterium tuberculosis infection and vaccine development, 2016; 98:30 - 41

5- WHO. Global tuberculosis report 2017. Licence: CC BY-NC-SA 3.0 IGO. ISBN 978 - 92 - 4 -156551- 6

6- Ibekwe, N.N., Ameh, S.J., Plant natural products research in tuberculosis drug discovery and development: A situation report with focus on Nigerian biodiversity. African Journal of Biotechnology 2015; 13 (23), $2307-2320$.

7- Proksch, P., Georgios, D., Rainer, K., Hendrik, K., Rudolf, H., Nicole, J., Victor, W., Wenhan, L., Callyaerins from the marine sponge Callyspongia aerizusa: cyclic peptides with antitubercular activity. Journal of Natural Products, 2015

8- Gordien, A.Y., Gray, A.I., Franzblau, S.G., Seidel, V., Antimycobacterial terpenoids from Juniperus communis L. (Cuppressaceae). Journal of Ethnopharmacology, 2009; 126:500-505.

9- Nguta, J.M., Regina, A.O., Nyarko, A.K., Manu, D.Y., Addo, P.G.A., Current perspectives in drug discovery against tuberculosis from natural products. International Journal of Mycobacteriology, 2015b; 4:165- 183.

10- Abdullahi, M., Amupitan, J.O., Oyewale, A.O., Okogun, J.I., Kolo, I., An ethnobotanical survey of indigenous flora for treating tuberculosis and other respiratory diseases in Niger State, Nigeria. Journal of Phytomedicine And Therapeutics; 2007; 12, 1-21.

11- Ogbole, O.O., Ajaiyeoba, E.O., Traditional management of tuberculosis in Ogun state of Nigeria: the practice and ethnobotanical survey. African Journal of Traditional, Complementary and Alternative Medicines, 2010; 7(1):79-84.

12- Aska, A.S., Kubmarawa, D., Preliminary Phytochemical Screening of Some Indigenous Medicinal Plants Used In the Treatment of Tuberculosis in Bauchi State, Nigeria. IOSR Journal of Applied Chemistry, 2016; 9 (4), 4852 .

13- Mutabana, N., Mpulusu, D., Plantes Médicinales cultivées dans la zone de Kabondo à Kisangani (Zaire). African Study Monographs, 1990; 11(2):8799.

14- Ladoh-Y, C.F., Vandi, T., Dibong, S.D., Mpondo, M.E., Wansi, J.D., Betti, J.L., Choula, F., Ndongo, D., Tomedi, E.M., Étude ethnobotanique des plantes médicinales commercialisées dans les marchés de la ville de Douala Cameroun. Journal of Applied Biosciences,2016; 99:9450-9466.

15- Ha, S.K., Moon, E., Ju, M.S., Kim, D.H., Ryu, J.H., Oh, M.S., Kim, S.Y., Shogaol, A Ginger Product, Modulates Neuroinflammation: A New Approach to Neuroprotection. Neuropharmacology, 2012; 63:211-23.

16- Haniadka, R., Saxena, A., Shivashankara, A.R., Fayad, R., Palatty, P.L., Nazreth, N., Francis, A., Arora, R., Baliga, M.S., Ginger Protects the Liver against the Toxic Effects of Xenobiotic Compounds: Preclinical Observations. Journal of Nutrition and Food Sciences 2013; 3:226.

17- Moustafa, B.H., Amal, K.M., Mohamed, E.R., Eman, H.G., A Review on Phenolic Compounds from Family Sapotaceae. Journal of Pharmacognosy and Phytochemistry 2016; 5(2):280-287.

18- Mpondo, M.E., Vandi, D., Ngouondjou, F.T., Mvogo, O.P.B., Embolo, E.E Dibond, S.D., Contribution des populations des villages du centre Cameroun aux traitements traditionnels des affections des voies respiratoires. Journal of Animal \& Plant Sciences 2017; 32(3):5223-5242.

19- Ballo, M.K., Etude phytochimique et l'évaluation de l'activité sur Mycobacterium tuberculosis in vitro de 22 plantes utilisées dans le traitement traditionnel de la tuberculose au Mali. Thèse de pharmacie, faculté de pharmacie. Université des sciences, des techniques et des technologies de Bamako, Mali, 2013.

20- Osadebe, P.O., Anti-infl ammatory properties of the root bark of Alstonia boonei. Nigerian Journal of Natural Products and Medicine 2002; 3:39- 41.

21- Prakash, P., Gupta, N., Thérapeutic uses of Ocimum sanctum (Tulsi) with a note on eugenol and its pharmacological actions : A Short Review. Indian Journal of Physiology and Pharmacology 2005; 49(2):125-131.

22- Sourabie, T.S., Nikiema, J.B., Guissou, I.P., Nacoulma, O.G., Etude comparée des effets anti-hépatotoxiques d'extraits d'Argemone mexicana $\mathrm{L}$ (Papaveraceae), une plante utilisée dans le traitement traditionnel de la jaunisse au Burkina Faso. International Journal of Biological. Chemical Sciences, 2012; 6(3):1139-1147.

23- Rong X., Peng G., Suzuki T., Yang Q., Yamahara J et Li Y. A 35-day gavage safety assessment of ginger in rats.Regulatory Toxicology and Pharmacology, 2009; 54(2):118-123.

24- Harborne, J.B., Phytochemical Methods: A Guide to Modern Techniques of Plant Analysis. (3rd edition). Chapman and Hall Co., New York, 1998; Pp, 1-302.

25- Evans, W.C., Trease and Evans Pharmacology, 4th Edn. WB Saunders Company Ltd, 2000; Pp, 224- 239.

26- Salie, F., Eagles, P.F.K., Leng, H.M.J., Preliminary antimicrobial screening of four South African Asteraceae species. Journal of Ethnopharmacology 1996; 52:27-33.

27- Collins, L., Franzblau, S.G., Microplate alamar blue assay versus BACTEC 460 system for high-throughput screening of compounds against Mycobacterium tuberculosis and Mycobacterium avium. Antimicrobial Agents and Chemotherapy, 1997; 41:1004-1009.

28- Carbonelle, B., Denis, F., Marmonier, A., Pinon, G., Vague, R., Bactériologie Médicale: Techniques Usuelles. SIMEP Edition, Paris, 1987; 228-282.

29- Gatsing, D., Mbah, J.A., Garba, I.H., Tane, P., Djemgou, P., Nji-Nkah, B.F., An Antisalmonellal Agent from the Leaves of Glossocalyx brevipes Benth (Monimiaceae). Pakistan Journal of Biological Sciences, 2006; 9:84-87.

30- OECD 423., OECD Guideline for testing of chemicals : Acute Oral Toxicity Acute Toxic Class Method; 2001

31- Mahmoudi, S., Khali, M., Mahmoudi, N., Etude de l'extraction des composés phénoliques de différentes parties de la fleur d'artichaut (Cynara scolymus L.). Revue " Nature \& Technologie ». B- Sciences Agronomiques et Biologiques 2013; 9:35-40.

32- Lehout, R., Laib, M., Comparaison de trois méthodes d'extraction des composés phénoliques et des flavonoïdes à partir de la plante médicinale : Artemisia herba alba Asso. Mémoire de Master en Biochimie moléculaire et santé. Université des Frères Mentouri Constantine, Algérie. 2015; Pp, 41.

33- Kémajou, A., Mba, L., Bagda, A.A., Effet du séchage sur les principes actifs des plantes médicinales : cas des alcaloïdes totaux des écorces de Alstonia boonei Wild, plante antipaludéenne. Nature \& Technology, 2012; 07 :62 66.

34- Mariangela, M., Francesco, M., Filomena, C., A comparative study of Zingiber officinale Roscoe pulp and peel: phytochemical composition and evaluation of antitumour activity. Natural Product Research, .2015; Pp, 3.

35- Bruneton, J., Pharmacognosie : Phytochimie, Plantes Médicinales. 3ème édition, Lavoisier Techniques \& Documentation, Paris 1999; Pp, 231-236.

36- Kpemissi, A., Les anacardiaceae du togo : études botaniques, écologiques et propriétés antifongiques. Thèse de doctorat des Universités de Reims Champagne-Andenne et Lomé. Togo. 2007; Pp, 80-83.

37- Ross, C.F., Hoye, C.Jr., Fernandez-Plotka, V.C., Influence of Heating on the Polyphenolic Content and Antioxidant Activity of Grape Seed Flour Journal of Food Science 2011; $76: 6$.

38- Kobo, P.I., Erin, P.J., Suleiman, M.M., Aliyu, H., Tauheed, M., Muftau, S., Mamman, M., Antitrypanosomal effect of methanolic extract of Zingiber officinale (ginger) on Trypanosoma brucei brucei-infected Wistar mice. Veterinary World, 2014; 7(10) :770-775.

39- Amari, S., Étude phytochimique et évaluation de l'activité antibactérienne et antioxydante de deux extraits de la plante Zingiber officinale. Mémoire de master en Sciences biologiques, option-biochimie appliqué. Université Abou Bekr Belkaid-Tlemcen, Algérie. 2016.

40- Ogudo, B.U., Lawal, T.O., Adeniyi, B.A., Extracts of Zingiber officinale Rosc (Ginger) and Curcuma longa Linn. (Turmeric) Rhizomes inhibited Nontuberculous Mycobacteria in vitro. Journal of Biology, Agriculture and Healthcare, 2014; $4: 12$.

41- Voukeng, I.k., Penlap, B.V., Kuete, V., Antibacterial activity of six medicinal Cameroonian plants against Gram-positive and Gram-n egative multidrug resistant phenotypes. BMC Complementary and Alternative Medicine, 2016; 16 :388. 
42- Opoku, F., Akoto, O., Antimicrobial and Phytochemical Properties of Alstonia Boonei Extracts. Organic Chemistry Current Research 2015; $1: 137$.

43- Owolabi, O.J., Arhewoh, I.M., Innih, S.O., Anaka, O.N., Monyei, C.F., The ethanol leaf extract of Alstonia boonei (Apocynaceae) reduces hyperglycemia in alloxan-induced diabetic rats. Nigerian Journal of Pharmaceutical Sciences 2014; 13(1) :12-21.

44- El-Mahmood, A.M., Doughari, J.H., Ladan, N., Antimicrobial screening of stem bark extracts of Vitellaria paradoxa against some enteric pathogenic microorganisms. African Journal of Pharmacy and Pharmacology 2008; 2(5):089-094.

45- Ndukwe, I.G., Amupitan, J.O., Isah, Y. and Adegoke, K.S., Phytochemical and antimicrobial screening of the crude extracts from the root, stem bark and leaves of Vitellaria paradoxa (GAERTN. F). African Journal of Biotechnology 2007; 6(16):1905-1909.

46- Fodouop, C.S.P., Tala, S.D., Lunga, K.P., Kodjio, N., Mefokou, Y.D., Nwabo, K.A.H., Nji-kah, B., Tchoumboue, J., Gatsing, D., Effects of Vitellaria paradoxa (C.F. Gaertn.) aqueous leaf extract administration on Salmonella typhimurium-infected rats. BMC Complementary and Alternative Medicine, 2017; $17: 160$.

47- Bruneton, J., Pharmacognosie : Phytochimie, Plantes Médicinales. 3ème édition, Lavoisier Techniques \& Documentation, Paris, 1999; Pp, 231236.

48- Nyegue, M.A., Propriétés chimiques et biologiques des huiles essentielles de quelque plantes aromatiques et/ou médicinales du Cameroun évaluation de leurs activités antiradicalaires, antiinflammatoires et antimicrobiennes. Thèse de doctorat des universités Montpellier II et Yaoundé I. Cameroun 2006; Pp, 46-143

49- Hudaib, M., Speroni, E., Di Pietra, A.M., Cavrini, V., GC/ MS evaluation of thyme (Thymus vulgaris $\mathrm{L}$.) oil composition and variations during the vegetative cycle. Journal of Pharmaceutical and Biomedical and Analysis 2002; $29: 691-700$.

50- Nguta Joseph. M., Appiah-Opong Regina., Nyarko Alexander. K., YeboahManu Dorothy., Addo Phyllis. G. A., Otchere Isaac., Kissi-Twum Abena. Antimycobacterial and cytotoxic activity of selected medicinal plant extracts. Journal of Ethnopharmacology, 2016; 182:10 - 15

51- Paiva, P.M.G., Gomes, F.S., Napoleão, T.H., R.A. Sá R. A., Correia, M.T.S. Coelho, L.C.B.B., Antimicrobial activity of secondary metabolites and lectins from plants. A. Méndez-vilas (Ed) 2010.

52- Cowan, M.M., Plant products as antimicrobial agents. Clinical Microbiology Reviews 1999; 12:564-582.

53- Thangara, J.H.S., Adjei, O., Allen, B.W., Portaels, F., In-vitro activity of ciprofloxacin, sparfloxacin, ofloxacin, amikacin and rifampicin against
Ghanian isolates of Mycobacterium ulcerans. Journal Antimicrobial Agents Chemoter 2000; 45 (2) :231-233.

54- Bhimba, B.V., Meenupriya, J., Lycias, J.E., Naveena, D.E., kumar, S., Thangaraj, M., Antibacterial activity and characterization of secondary metabolites isolated from mangrove plant Avicennia officinalis. Asian Pacific Journal of Tropical Medicine 2010; Pp, 412-420.

55- Kuete, V., Potential of Cameroonian plants and derived products against microbial infections : A Review. Planta Medica 2010; 76 :1479-1491.

56- Gordien Andréa Y., Gray Alexander I., Franzblau Scott G., Seidel Véronique. Antimycobacterial terpenoids from Juniperus communis L. (Cuppressaceae). Journal of Ethnopharmacology 2009; 126:500-505

57- Brent Copp R. Antimycobacterial natural products. Nat. Prod. Rep 2003; 20:535-557

58- Kuete, V., Tangmouo, J.G., Meyer, M.J.J., Lall, N. Diospyrone, crassiflorone and plumbagin: three antimycobacterial and antigonorrhoeal naphthoquinones from two Diospyros spp. International Journal of Antimicrobial Agents, 2009; 34:322-325.

59- Hiserodt, R.D., Franzblau, S.G., Rosen, R.T. Isolation of 6-, 8-, and 10Gingerol from Ginger Rhizome by HPLC and Preliminary Evaluation of Inhibition of Mycobacterium avium and Mycobacterium tuberculosis. Journal of Agricultural and Food Chemistry, 1998; 46, 2504-08.

60- Raju, A., Degani, M.S., Khambete, M.P., Ray, M.K., Rajan, M.G.R. Antifolate activity of plant polyphenols against Mycobacterium tuberculosis. Phytotherapy Research 2015; $29: 1646-1651$.

61- Adotey, K.J.P., Adukpo, E.G., Boahen, O.Y., Armah, A.F., A Review of the Ethnobotany and Pharmacological Importance of Alstonia boonei De Wild (Apocynaceae). International Scholarly Research Network Pharmacology 2012; P, 9.

62- OECD. Harmonised Integrated Hazard Classification for Human Health and Environmental Effects of Chemical Substances as endorsed by the 28th Joint Meeting of the Chemicals Committee and the Working Party on Chemicals in November 1998, Part 2, P.11. [http://webnet1.oecd.org/oecd/pages/home/displaygeneral/0,3380,ENdocuments-521-14-no-24-no-0,FF.html]. (Consulté le 4 Avril 2018).

63- Mainasara, A.S., Oduola, T., Musa, U., Mshelia, A.S., Muhammed, A.O., Ajayi, A.S., . Hepatotoxicity Assessment in Wistar Rats Exposed to Vitellaria paradoxa Stem Bark Extract. European Journal of Medicinal Plants 2016a;13(3):1-9.

64- Mainasara, A.S., Oduola, T., Musa, U., Mshelia, A.S., Muhammed, A.O., Ajayi, A.S., Effect of Vitellaria paradoxa Stem Bark Ingestion on Kidney Functions in Wistar Rats. British Journal of Pharmaceutical Research 2016b ;11(2):1-8 